\title{
Language Learning Strategy Use and Reading Achievement
}

\author{
Narjes Ghafournia ${ }^{1}$ \\ ${ }^{1}$ Department of English, Neyshabur Branch, Islamic Azad University, Neyshabur, Iran \\ Correspondence: Narjes Ghafournia, Department of English, Neyshabur Branch, Islamic Azad University, \\ Neyshabur, Iran. Tel: 98-915-313-0060. E-mail: narjesghafournia@yahoo.com
}

Received: December 31, 2013 Accepted: February 25, 2014 Online Published: March 6, 2014

doi:10.5539/elt.v7n4p64 URL: http://dx.doi.org/10.5539/elt.v7n4p64

\begin{abstract}
The current study investigated the differences across the varying levels of EFL learners in the frequency and choice of learning strategies. Using a reading test, questionnaire, and parametric statistical analysis, the findings yielded up discrepancies among the participants in the implementation of language-learning strategies concerning their reading achievement. The participants comprised 307 Iranian BA students doing a general English course at Teacher-Training University of Mashhad. The results suggest that as the learners' reading ability improves, the learners are more inclined to choose strategies to facilitate reading processing, which is reflective of greater autonomy for language learning. Thus, the results imply that appropriate employment of language-learning strategies can foster individual autonomy and hence reduce affective filters to process reading texts in an efficient way. The findings are consistent with previous studies on the inconsistency among learners with different reading ability in employing language-learning strategies and comprehension process. Thus, the findings further support integrating strategy training into conventional teaching approaches to enhance efficacy of reading programs. Through adopting strategic-based instruction, teachers can help learners become aware of available strategies, the way to organize them systematically, and the way they can transfer the strategies to new language learning contexts (Cohen, 2007).
\end{abstract}

Keywords: learning strategies, autonomy, strategic awareness, reading ability

\section{Introduction}

Since 1970, learning strategies have been at the center of attention for many researchers working on the cognitive process of second language learning (e.g. Anderson, 1991, 2003; Cohen, 1990, 1998; Hosenfeld, 1979; Macaro, 2001; O’Malley \& Chamot, 1990; Oxford, 1990, 1993, 2002; Rubin, 1975; Stern, 1975; Wenden, 1991, 2002). Many researchers shared ideas about learning strategies and their functions in the process of second language learning (e.g., Bialystok, 1990; Oxford, 1990, 1996; Pressley \& McCormick, 1995). They definedthe strategies as essential techniques intentionally and consciously used by language learners for effective understanding, remembering, and using information. Thus, a number of researchers have focused on the strategic process of learning and the types of strategies most frequently used by successful language learners as well as the conditions under which these strategies are employed by proficient learners (e.g., Anderson, 2003; Goh, 1998, 1999; O’Maley et al., 1989; Rasekh \& Ranjbary, 2003; Vandergrift, 1996, 1997; Young, 1997). The findings of these studies support the fact that successful language learners take conscious stepsto understand what they are doing through using a wider range of strategies than do less successful learners. The general findings of some studies have demonstrated that high degrees of strategic awareness helps language learners act better atprocessing and storing new information, find the best ways to practice and reinforce what they have learned (Vandergrift et al., 2006), and enhance thinking and comprehending (Costa, 2001; Sternberg, 1998; Wenden, 1998). More proficient language learners often use a greater variety of learning strategies and differ in the way the strategies are applied for accomplishing certain tasks (Bruen, 2001; Chamot \& El-Dinary, 1999; Green \& Oxford, 1995; O'Malley \& Chamot, 1990; Wharton, 2000). Some studies have demonstrated a direct association between L2 learners' affective factors such as self-confidence, language ability, and a range of learning strategies they utilize to perform certain tasks (e.g, Khaldieh, 2000).

Although language proficiency has been found to be consistently linked with strategy use in many studies (e.g., Green \& Oxford, 1995; Khaldieh, 2000; Lan \& Oxford, 2003; Su, 2005; Wharton, 2000), the findings of some studies suggestthat the relationship is more complex than a simple linear relationship due to the type of strategies employed in particular settings. As an example, Chen (1990) found that the learners that were more 
proficientused communication strategies more effectively than did the learners that were less proficient. In addition, due to the correlational nature of most of the studies, the findings cannot easily reveal the casual relationship between proficiency level and employing learning strategies (Mahlobo, 2003). In other words, the findings of many studiescannot determine whetherlearners' language proficiency comes before, after, or concurrently with the employment of learning strategies (Halbach, 2000).

The complexity of the relationship has raised unanswered questions among some researchers (e.g., Dörnyei, 2005; Ehrman et al., 2003; Macaro, 2001; MacIntyre, 2002). Bremner regarded the relationship between learners' language proficiency and strategy use as the cause and effect relationship locked in a mutual interaction. McDonough (1999) also stressed the complexity and believed that the frequency and quality of strategy use do not simply follow a simple linear relationship.

The paramount role of implementing learning strategies to smooth reading comprehension process has been widely acknowledged despite the complex nature of processing reading texts (e.g., Bernhardt, 2005; Day \& Bamford, 2002; Grabe, 2004; Hudson, 2007). However, improving strategic reading ability in a second language does not develop easily. There exist many second language readers withadequate language competency, but with major difficulties in coping with academic texts in a thorough way (Eskey, 2005; Phan, 2006; Snow, 2002; Wen, 2003). Shokrpourand Fotovatian (2009) believed that these students do not have sufficient strategic awareness to control their reading process andthe way to use them properly. As a result, they feel perplexed and cannot adoptan appropriate approach to improve their reading ability. Strategic processing of reading texts plays an essential part in achieving comprehension goals and removing reading difficulties (Phan, 2006). When learners possess strategic knowledge, they will understand their thinking process and oversee the choice and application of learning strategies. Having this knowledge, they can find solutions to the probable problems (Goh, 2008; Zhang \& Goh, 2006). Given this, language teachers should strive to develop students' own metacognition and teach them how to use the strategies effectively for accomplishing different kinds of reading tasks.

In spite of consensus on the significance of strategic awareness, more studies are required to be carried out with different populationsand various reading goals to remove the unclear points. Thus, the present study was designed to investigate university students' strategic awareness of academic reading comprehension process at different levels of reading ability. The results could provide language instructors helpful hints for improving instructional approaches. The study also explores the strategies applied more frequently by successful learners to assist language teachers in improving teaching approaches to bridge the gap between more successful and less successful learners.

\section{Empirical Background}

The use of wider range of language-learning strategies by more proficient language learners has been proved by many researchers (e.g., Dreyer \& Oxford, 1996; Green \& Oxford, 1995; Liu, 2004; Nisbet et al., 2005; Oxford, 1996; Oxford \& Ehrman, 1995; Vandergrift et al., 2006). More specifically, the interaction between learners' level of language proficiency and using direct as well as indirect learning strategies has been reported by some researchers (e.g., Chen, 2002; Green \& Oxford, 1995; Park, 1997; Vandergrift et al., 2006).

Many researchers investigated L2 learners' strategic patterns in different learning settings (e.g., El-Dib, 2004; Green \& Oxford, 1995; Ok, 2003; Su, 2005; Wharton, 2000). As an example, Green and Oxford investigated the relationship between language-learning strategy and second language proficiency level of 374 university students in Puerto Rico, who were divided into three groups of language ability based on their scores on the English placement test. The findings showed that the learners that were more proficient used overall strategies and different strategy categories more frequently than the learners that were less proficient. The learners that were more proficient also used the strategies more interactively than did the learners that were less proficient. Wharton investigated the strategic patterns of 678 university students learning Japanese and French as foreign languages in Singapore. The results showed that the learners that were more proficient adopted more strategy use than did the learners that were less proficient. Su investigated the strategic behavior of 419 vocational college students in Taiwan concerning their self-assessed level of language proficiency. The findings showed linear relationship between use of learning strategies and level of language proficiency. In the Arabic context, El-Dib examined the relationship between language ability and application of language-learning strategies by $750 \mathrm{EFL}$ learners, selected from four universities in Kuwait. Using reclassified factor analysis, El-Dib proved that more proficient language learners preferred to use active naturalistic strategies more frequently whereas less proficient learners preferred to use affective strategies more frequently.

In Iranian contexts, Bidabadi and Yamat (2011) investigated the relationship between learning strategiesused by Iranian EFL freshman university students and their reading proficiency. The findings manifested that the students 
used metacognitive strategies more frequently, followed by cognitive andsocio-affective strategies. The results were in congruent with Rahimi and Katal's (2011) study on the effect of strategic awareness on learning English. Javadi et al. (2010) investigated the relationship between strategic awareness of reading andthe students' academic statusand achievement at Isfahan University. The results revealed that advanced students used more cognitive and metacognitive strategies thandid weak students. Pishghadam (2009) investigated the preferred learning strategies utilized by Iranian students. Through administrating Oxford's (1990) language-learning strategies inventory among three thousands Iranian university students, the resultsdemonstrated that Iranian students used metacognitive strategies most frequently and affectivestrategies least frequently. Akbari (2003) administered Oxford's (1990) questionnaire to 128 Iranian EFL university studentsand investigated the interaction between using learning strategies and their foreign language proficiency. The results demonstrated thatmetacognitive strategies were used more than other strategies. Besides, advanced students preferred to use cognitive, metacognitive, andcompensation strategies more frequently than other strategies.

Concerning the fact that language-learning strategies make a substantial contribution to the cognitive processing of language learning, the present study seeks to analyze the effectiveness of implementing certain strategies on the process of reading comprehension in an EFL setting. The effect of employing certain strategies on reading achievement is explored via reading comprehension test performance of many EFL learners. Since improving academic reading is an essential part of many language-teaching programs and focus of concern at higher educational programs, the study seeks the effectiveness of reading strategies on developing reading ability of university students in an Iranian context. The findings can provide important insights into the way language is cognitively processed, which can contribute to pedagogical understanding and teaching methods.

The following research questionsare addressed in this study:

1) What is the relationship between language-learning strategies and reading ability of Iranian EFL learners?

2) What strategies are used most frequently by successful Iranian EFL learners?

\section{Method}

The participants, materials, procedures, and data analysis are discussed in this section.

\subsection{Participants}

Out of 410 students, 307 Iranian BA students doing a general English course at Teacher-Training University of Mashhad contributed in the study. They formed three groups of reading ability according to their scores on the reading section of an IELTS test. They were in the 22-28 age range, forming a similar proportion of males and females. The criterions for selecting the participants were accessibility, active contribution, and complete accomplishment of the test and the questionnaire, utilized as the major materials used in this study.

\subsection{Materials}

A reading comprehension test, derived from Cambridge Practice Tests for IELTS 1, was administered to all the participants. The test comprised three reading excerpts, followed by 41 questions. Eight language teachers also checked the content of the test. Before the actual administration of the test, it was administered to a sample of 36 students for the empirical validation. Reliability analysis with this instrument demonstrated high level of internal consistency $(\alpha=0.83)$. The time given to take the actual test was 90 minutes. All the participants also answered a questionnaire asking about the strategies they actually used to facilitate their reading processes. The questionnaire items were adapted from Oxford's (1990) classification, which is comprehensiveand systematic. To establish the validity and reliability, the questionnaire content was checked by seven experts in TEFL and administered to a sample of 36 students. Cronbachalpha coefficient $(\alpha=.850)$, yielded a high reliability estimate. The time given to complete the questionnaire was 30 minutes.

\subsection{Procedure}

The actual participants attended a single data collection session, lasting about 120 minutes. At the beginning, theparticipants were directed to answer the test that lasted about 90 minutes. Afterwards, they were asked to complete the questionnaire in about 30 minutes. More time was given to those participants who were not able to fill out the questionnaire in the due time. Prior to the actual administration of the test and questionnaire, the students were briefed well on the structure of the test and questionnaire items, and the probable ambiguities were removed by the researcher. Thequestionnaire was validated through asking some experts in TEFL to check it and revise the ambiguous items. Besides, it was administered to a sample similar to the actual sample, who gave feedback on the content of the questionnaire to improve the items. In addition, the reliability index of the questionnaire was calculated. 


\subsection{Data Analysis}

The 19th version of SPSS software was utilized to conduct required statistical analysis. Parametric statistical analysis was utilized to calculatedescriptive statistics, one-way analysis of variance, and Scheffe Test. Descriptive statistics were applied to examine the mean scores and standard deviations of using learning strategies. A one-way analysis of variance was utilized to explore whether there were any significant differences among the mean scores of using different strategies by the participants. Scheffe test was used for multiple comparisons among the means and locating the significant differences.

\section{Results and Discussion}

To analyze the relation between reading ability and learningstrategies, descriptive statistics was calculated. Table 1 shows the results.

Table 1. Descriptive statistics for learning strategies

\begin{tabular}{|c|c|c|c|c|c|c|c|}
\hline Strategies & Proficiency Level & $\mathrm{N}$ & Mean & Std. Deviation & Std. Error & Min & Max. \\
\hline \multirow{4}{*}{$\begin{array}{l}\text { Overall } \\
\text { Strategies }\end{array}$} & Low & 48 & 3.1392 & .50089 & .07230 & 1.57 & 3.94 \\
\hline & Intermediate & 240 & 3.0960 & .47685 & .03078 & 1.85 & 4.47 \\
\hline & High & 19 & 3.5411 & .45296 & .10392 & 2.78 & 4.19 \\
\hline & Total & 307 & 3.1303 & .48951 & .02794 & 1.57 & 4.47 \\
\hline \multirow{4}{*}{$\begin{array}{l}\text { Memory } \\
\text { Strategies }\end{array}$} & Low & 48 & 3.1665 & .60190 & .08688 & 1.88 & 4.44 \\
\hline & Intermediate & 240 & 3.1560 & .56567 & .03651 & 1.67 & 4.89 \\
\hline & High & 19 & 3.4789 & 61994 & .14222 & 2.33 & 4.44 \\
\hline & Total & 307 & 3.1777 & .57810 & .03299 & 1.67 & 4.89 \\
\hline \multirow{4}{*}{$\begin{array}{l}\text { Cognitive } \\
\text { Strategies }\end{array}$} & Low & 48 & 3.1421 & .48305 & .06972 & 1.67 & 4.14 \\
\hline & Intermediate & 240 & 3.0592 & .53096 & .03427 & 1.87 & 4.53 \\
\hline & High & 19 & 3.5400 & .52596 & .12066 & 2.67 & 4.33 \\
\hline & Total & 307 & 3.1019 & .53471 & .03052 & 1.67 & 4.53 \\
\hline \multirow{4}{*}{$\begin{array}{l}\text { Compensation } \\
\text { Strategies }\end{array}$} & Low & 48 & 3.3352 & .66747 & .09634 & 1.17 & 4.50 \\
\hline & Intermediate & 240 & 3.2643 & .72670 & .04691 & 1.17 & 5.00 \\
\hline & High & 19 & 3.7553 & .56251 & .12905 & 2.83 & 4.67 \\
\hline & Total & 307 & 3.3058 & .71662 & .04090 & 1.17 & 5.00 \\
\hline \multirow{4}{*}{$\begin{array}{l}\text { Metacognitive } \\
\text { Strategies }\end{array}$} & Low & 48 & 3.4523 & .77831 & .11234 & 1.80 & 4.60 \\
\hline & Intermediate & 240 & 3.3390 & .68536 & .04424 & 1.50 & 5.00 \\
\hline & High & 19 & 3.9337 & .37565 & .08618 & 3.30 & 4.60 \\
\hline & Total & 307 & 3.3935 & 69943 & .03992 & 1.50 & 5.00 \\
\hline \multirow{4}{*}{$\begin{array}{l}\text { Affective } \\
\text { Strategies }\end{array}$} & Low & 48 & 2.6565 & .68124 & .09833 & 1.17 & 4.40 \\
\hline & Intermediate & 240 & 2.7253 & .71513 & .04616 & 1.00 & 4.83 \\
\hline & High & 19 & 3.0526 & .62156 & .14260 & 1.83 & 4.00 \\
\hline & Total & 307 & 2.7348 & .70764 & .04039 & 1.00 & 4.83 \\
\hline \multirow{4}{*}{$\begin{array}{l}\text { Social } \\
\text { Strategies }\end{array}$} & Low & 48 & 2.8942 & .80224 & .11579 & 1.29 & 4.57 \\
\hline & Intermediate & 240 & 2.9295 & .76024 & .04907 & 1.14 & 4.86 \\
\hline & High & 19 & 3.3053 & .83274 & .19104 & 1.57 & 4.43 \\
\hline & Total & 307 & 2.9473 & .77440 & .04420 & 1.14 & 4.86 \\
\hline
\end{tabular}

As given in the table, more proficient students reported more frequent use of overall strategies as well asdifferent subcategories of the strategies than did less proficient students. A one-way ANOVA was conducted to examine the differences among the means of the groups in employing the strategies. Table 2 yields the results. 
Table 2. One-way ANOVA for learning strategies

\begin{tabular}{|c|c|c|c|c|c|c|}
\hline & & Sum of Squares & df & Mean Square & $\mathrm{F}$ & Sig. \\
\hline \multirow{3}{*}{$\begin{array}{l}\text { Overall } \\
\text { Strategies }\end{array}$} & Between Groups & 3.492 & 2 & 1.746 & 7.602 & .001 \\
\hline & Within Groups & 69.830 & 304 & .230 & & \\
\hline & Total & 73.323 & 306 & & & \\
\hline \multirow{3}{*}{$\begin{array}{l}\text { Memory } \\
\text { Strategies }\end{array}$} & Between Groups & 1.843 & 2 & .921 & 2.789 & .063 \\
\hline & Within Groups & 100.422 & 304 & .330 & & \\
\hline & Total & 102.265 & 306 & & & \\
\hline \multirow{3}{*}{$\begin{array}{l}\text { Cognitive } \\
\text { Strategies }\end{array}$} & Between Groups & 4.162 & 2 & 2.081 & 7.593 & .001 \\
\hline & Within Groups & 83.326 & 304 & .274 & & \\
\hline & Total & 87.488 & 306 & & & \\
\hline \multirow{3}{*}{$\begin{array}{l}\text { Compensation } \\
\text { Strategies }\end{array}$} & Between Groups & 4.293 & 2 & 2.146 & 4.269 & .015 \\
\hline & Within Groups & 152.850 & 304 & .503 & & \\
\hline & Total & 157.143 & 306 & & & \\
\hline \multirow{3}{*}{$\begin{array}{l}\text { Metacognitive } \\
\text { Strategies }\end{array}$} & Between Groups & 6.423 & 2 & 3.211 & 6.814 & .001 \\
\hline & Within Groups & 143.274 & 304 & .471 & & \\
\hline & Total & 149.697 & 306 & & & \\
\hline \multirow{3}{*}{$\begin{array}{l}\text { Affective } \\
\text { Strategies }\end{array}$} & Between Groups & 2.235 & 2 & 1.118 & 2.250 & .107 \\
\hline & Within Groups & 150.994 & 304 & .497 & & \\
\hline & Total & 153.230 & 306 & & & \\
\hline \multirow{3}{*}{$\begin{array}{l}\text { Social } \\
\text { Strategies }\end{array}$} & Between Groups & 2.646 & 2 & 1.323 & 2.224 & .110 \\
\hline & Within Groups & 180.863 & 304 & .595 & & \\
\hline & Total & 183.509 & 306 & & & \\
\hline
\end{tabular}

Table 2 shows significant differences among the three groups in utilizing overall, $F(2,304)=7.602, p=.001$; cognitive, $F(2,304)=7.593, p=.001$; andmetacognitive strategies $F(2,304)=6.814, \mathrm{p}=.001$. Scheffe test was utilized to analyze the differences in detail. Table 3 yields the results.

Table 3. Scheffe test for mean scores

\begin{tabular}{|c|c|c|c|c|c|c|c|}
\hline \multirow{2}{*}{$\begin{array}{l}\text { Dependent } \\
\text { Variable }\end{array}$} & \multirow{2}{*}{$\begin{array}{l}\text { (I) Reading } \\
\text { Level }\end{array}$} & \multirow{2}{*}{$\begin{array}{l}\text { (J) Reading } \\
\text { Level }\end{array}$} & \multirow{2}{*}{$\begin{array}{c}\text { Mean Difference } \\
(\mathrm{I}-\mathrm{J})\end{array}$} & \multirow{2}{*}{ Std. Error } & \multirow{2}{*}{ Sig. } & \multicolumn{2}{|c|}{$95 \%$ Confidence Interval } \\
\hline & & & & & & Lower Bound & Upper Bound \\
\hline \multirow{6}{*}{$\begin{array}{l}\text { Overall } \\
\text { Strategies }\end{array}$} & \multirow{2}{*}{ Low } & Intermediate & .04321 & .07578 & .850 & -.1432 & .2296 \\
\hline & & High & $-.40189^{*}$ & .12990 & .009 & -.7214 & -.0823 \\
\hline & \multirow{2}{*}{ Intermediate } & Low & -.04321 & .07578 & .850 & -.2296 & .1432 \\
\hline & & High & $-.44509^{*}$ & .11422 & .001 & -.7261 & -.1641 \\
\hline & \multirow{2}{*}{ High } & Low & $.40189^{*}$ & .12990 & .009 & .0823 & .7214 \\
\hline & & Intermediate & $.44509^{*}$ & .11422 & .001 & .1641 & .7261 \\
\hline \multirow{7}{*}{$\begin{array}{l}\text { Cognitive } \\
\text { Strategies }\end{array}$} & \multirow{2}{*}{ Low } & Intermediate & .08292 & .08278 & .606 & -.1207 & .2865 \\
\hline & & High & $-.39792^{*}$ & .14190 & .021 & -.7470 & -.0489 \\
\hline & \multirow{2}{*}{ Intermediate } & Low & -.08292 & .08278 & .606 & -.2865 & .1207 \\
\hline & & High & $-.48083^{*}$ & .12477 & .001 & -.7878 & -.1739 \\
\hline & \multirow{3}{*}{ High } & Low & $.39792^{*}$ & .14190 & .021 & .0489 & .7470 \\
\hline & & Intermediate & $.48083^{*}$ & .12477 & .001 & .1739 & .7878 \\
\hline & & Intermediate & $.45499^{*}$ & .13685 & .004 & .1184 & .7916 \\
\hline
\end{tabular}




\begin{tabular}{lccccccc}
\hline & \multirow{2}{*}{ Low } & Intermediate & .11329 & .10855 & .581 & -.1537 & .3803 \\
& & High & $-.48139^{*}$ & .18607 & .037 & -.9391 & -.0237 \\
\cline { 2 - 7 } $\begin{array}{l}\text { Metacognitive } \\
\text { Strategies }\end{array}$ & \multirow{2}{*}{ Intermediate } & Low & -.11329 & .10855 & .581 & -.3803 & .1537 \\
\cline { 2 - 7 } & & High & $-.59468^{*}$ & .16361 & .002 & -.9971 & -.1922 \\
\cline { 2 - 7 } & \multirow{2}{*}{ High } & Low & $.48139^{*}$ & .18607 & .037 & .0237 & .9391 \\
& & Intermediate & $.59468^{*}$ & .16361 & .002 & .1922 & .9971 \\
\hline
\end{tabular}

Significant differences were reported between the high and low proficiency groups in applying overall, cognitive, and metacognitive strategies at $\mathrm{p} \leq .05$.

Overall, the findings manifest most frequent use of learning strategies by successful learners, which may be indicative of a direct relationship between strategic processing and reading ability. The learners that were more successful used certain strategies, particularly cognitive and metacognitive strategies, the interaction of which facilitates comprehension process. The most frequent cognitive strategies applied by the students with high reading ability were skimming reading texts, using new words and idioms in other contexts of language use, reading English books and magazines in free time, using a dictionary to check the meaning of unknown words, reading intensively, and comprehending reading content without translation. The most frequent metacognitive strategies applied by the students that were more proficient were planning to learn effective ways to improve reading ability, identifying the weaknesses, setting specific goals, assessing reading ability, and planning regular schedules to improve reading ability. More successful learners also reported frequent use of a variety of other strategies such as recalling word meanings, guessing the meanings of unknown words from contextual clues, predicting topics and content of passages from an introductory paragraph, discriminating between more important and less important ideas, analyzing reference words, drawing inferences from the content, summarizing the content of the given text, finding main ideas, scanning and skimming text for general and specific information, and findingexplicit or implicit answers to questions. Successful learners also implemented resourcing strategies such as grouping, note-taking, summarizing, deduction, auditory representation, inference, and practicing strategies. The finding supported the earlier studies in that advanced learners much preferred to use metacognitive and cognitive strategies (e.g., Khalil, 2005; Su, 2005).

Regardless of reading ability, the participants favored implementation of metacognitiveand cognitive strategies over the other strategies. This implies that language-teaching programs should be highly metacognitive/cognitive-centereddespite the fact that many teachers conventionally favor working on memory strategies in most of classroom activities. Typical examples of using memory strategies in classroom settings are grouping, associating, placing new vocabularies in a context, using key words, representing sounds in memory, repeating, and reviewing.

Detailed analysis manifested that many proficient learners had sufficient linguistic knowledge in different areas of language due to engaging in some extracurricular activities such as learning English at different institutes, reading English books and magazines, watching TV programs in English, and using different self-instructional materials. The findings imply that proper application of learning strategies smoothes reading comprehension processing. The more the students uselearning strategies, the more likely they obtain higher scores on reading comprehension tests. The findings of this study are congruent with the earlier studies (e.g., Anderson, 2003; Goh, 1998, 1999; O’Maley et al., 1989; Rasekh \& Ranjbary, 2003; Vandergrift, 1996, 1997; Young, 1997) shedding light on the innovative approaches to improve academic reading. The findings are congruent with some theories on the positive effect of strategic awareness on second language reading (e.g., Lawrence, 2007; Pressley \& Gaskin, 2006) and hence inform teachers of the very essence of fostering the strategic behavior of learners to facilitate reading process. The findings also lend support to the idea that EFL teachers should integrate strategy training into reading instruction, helping language learners become and strategically self-regulated. The findings lend support to the idea that students should obtain a good command of language and reading strategies to be effective readers (Bernhardt \& Kamil, 1995; Kim, 1995).

The findings of this study also place emphasis on incorporating learning strategies into language courses to provide learners with greater opportunities touse language in an autonomous and self-directed way. Language learners should capitalize on their language treasure as well as strategic potentiality to improve reading efficacy. Teachers should provide learners with relevant instruction and supplementary materials to develop independent andcreative use of language, which is less teacher-centered. Thus, teachers are required to explain the discrepancy between students' views on the strategies and the actual practice with regard to different 
psychological factors such as perception, motivation, beliefs, confidence, etc.

Chamot (2004) acknowledged the benefits of direct strategy instruction and the importance of integrating strategy instruction into regular language teaching programs. Teachersshould be good models of strategic thinking, identifying strategies, practicing and applying strategies, and self-evaluation. Teachers should beaware of learners' strategy use and their needs. They should also scrutinize whether their teaching is compatible with their students' learning needs. In spite of theadvantages of strategy instruction, some variables should be taken into consideration such as direct versus indirect instruction, development of instructional materials, evaluation of strategy instruction, and appropriate teachers' training programs.

\section{Conclusion}

The study was an empirical investigation into the probable discrepancies among learners with varying reading knowledge foundation in the employment of language-learning strategies. As great proportion of academic materials is written in English, strong reading comprehension is of the essence for university students to extract academic information in different subject areas. However, many students are not skillful enough to cope with the instructional demands. The majority of these students do not possess ample linguistic and strategic knowledge to carry out reading tasks successfully, which certainly leads to the feeling of frustration and annoyance. Thus, the majority of learners place increasing demands on language teachers to resolve the conflict. To act as a skillful readers, students should not only possess enough linguistic foundation but also a wide array of reading strategies at their disposal, and the knowledge of where, when, and how to use these strategies. Thus, integrating strategy instruction into conventional language instruction should remain a high priority. However, language teachers should not enforce separation between teaching linguistic and strategic dimensions of language. Instead, they should teach linguistic and strategic aspects of language interactively as two interrelated components of communicative language ability. Research on metacognitive knowledgeand language learning has acknowledged the fact that metacognitive knowledge should be incorporated in language-teaching programs to make learning efficient (Zhang \& Goh, 2006). Strategy instruction should not only focus on teaching learning strategies but also on developing effective ways to enable learners to express their responsibility for their own learning. Oxford (1990) stated that the general goal of strategic-based instruction is to make language learning meaningful and to encourage a collaborative spirit between learners and teachers to facilitate self-reliance. She also believed that strategy training should be theoretical, practical, motivating, and funny to be helpful for students. Dörnyei (2005) also asserted that strategy instruction should foster learners to be conscious of learning process, choose, and apply relevant strategies.

The findings of this study manifested that more successful language learners utilized cognitive, metacognitive, memory, and compensation strategies more frequently than did less successful learners. Consequently, language teachers should make an effort to help less proficient language learners to work on particular dimensions of strategic processing to improve their reading comprehension ability. Detailed analysis also revealed that the participants expressed positive attitudes towards learning how to use learning strategies to facilitate reading comprehension process. They mentioned that they preferred to be exposed to direct strategic-based instructional programs, which provide them with teachers' explanations on the utilization of the strategies along with clear examples. However, if direct instruction is not practicable due to strictlydictated traditional syllabuses in most of language-teaching programs, language learners can use supplementary materials or self-instructional materials to improve their strategic processing potentialities independently. In general, it is inferred that improving strategic processing of language learners is related to their language ability, instructional approaches, and psychological factors such as attitude and motivation.

\section{References}

Akbari, R. (2003). The relationship between the use of language learning Strategies by Iranian learners of English, their foreign language Proficiency, and the learners' IQ scores. IJAL, 6, 1-20. Retrieved from www.sid.ir

Anderson, N. J. (1991). Individual differences in strategy use in second language reading and testing. Modern Language Journal, 75, 460-472. http://dx.doi.org/10.1111/j.1540-4781.1991.tb05384.x

Anderson, N. J. (2003). Metacognitive reading strategies increase L2 performance. The Language Teacher, 27 , 20-22.

Bernhardt, B., \& Kamil, M. (1995). Integrating relationship between L1 and L2 reading: Consolidating the linguistic threshold and linguistic interdependence hypotheses. Applied Linguistics, 16, 15-34.

Bidabadi, F., \& Yamat, H. (2011). The Relationship between Listening Strategies Used by Iranian EFL Freshman 
University Students and Their Listening Proficiency Levels. English Language Teaching, 4(1).

Bruen, J. (2001). Strategies for success: Profiling the effective learner of German. Foreign Language Annals, 34(3), 216-225. http://dx.doi.org/10.1111/j.1944-9720.2001.tb02403.x

Chamot, A. U. (2004). Issues in Language Learning Strategy Research and Teaching. Electronic Journal of Foreign Language Teaching, 1 .

Chamot, A. U., \& El-Dinary, P. B. (1999). Children's learning strategies in immersion classrooms. The Modern Language Journal, 83(3), 319-341.

Chen, S. Q. (1990). A study of communication strategies in interlanguage production by Chinese EFL learners. Language Learning, 40, 155-187.

Cohen, A. D. (1990). Language learning: Insights for learners, teachers, and researchers. New York: Newbury House.

Cohen, A. D. (1998). Strategies in learning and using a second language. Harlow: Longman.

Cohen, A. D. (2007). Styles- and Strategies-Based Instruction (SSBI). Retrieved March, 2009, from www.carla.umn.edu/strategies/SBIinfo.html

Costa, A. L. (Ed.). (2001). Developing minds: A resource book for teaching thinking (3rd ed.). Alexandria, VA: Association for Supervision and Curriculum Development.

Dörnyei, Z. (2005). The psychology of the language learner: Individual differences in second language acquisition. Mahwah, N. J. Lawrence Erlbaum Associates.

Dreyer, C., \& Oxford, R. (1996). Prediction of ESL proficiency among Afrikaans-speakers in South Africa. In R. Oxford (Ed.), Language learning strategies around the World: Cross-cultural Perspectives. Second Language Teaching and Curriculum Center, University of Hawaii: Honolulu.

Ehrman, M. E., Leaver, B. L., \& Oxford, R. L. (2003). A brief overview of individual differences in second language learning. System, 31, 313-330.

El-Dib, M. A. B. (2004). Language learning strategies in Kuwait: Links to gender, language level, and culture in a hybrid context. Foreign Language Annals, 37, 85-95.

Eskey, D. E. (2005). Reading in a second language. In E. Hinkel (Ed.), Handbook of research in second language teaching and learning (pp. 563-580). Mahwah, NJ: Lawrence Erlbaum Associates.

Goh, C. (1998). How learners with different listening abilities use comprehension strategies and tactics. Language Teaching Research, 2, 124-147.

Goh, C. (1999). What learners know about the factors that influence their listening comprehension? Hong Kong Journal of Applied Linguistics, 4, 17-42.

Goh, C. (2008). Metacognitive instruction for second language listening development: Theory, practice and research implications. Regional Language Centre Journal, 39(2), 188-213.

Green, J. M., \& Oxford, R. (1995). A closer look at learning strategies, L2 proficiency, and gender. TESOLQuarterly, 29(2), 261-297.

Hosenfeld, C. (1979). A learning-teaching view of second language instruction. Foreign Language Annals, 12, 51-57.

Halbach, A. (2000). Finding out about students' learning strategies by looking at their diaries: A case study. System, 28, 85-96. http://dx.doi.org/10.1016/S0346-251X(99)00062-7

Javadi, M., Keyvanara, M., Yaghoobbi, M., Hassanzade, A., \& Ebadi, Z. (2010). The Relationship between metacognitive awareness of reading strategies and students' academic status in Isfahan University of Medical Sciences. Iranian Medical Science Journal, 3(10), 246-254. Retrieved from www.sid.ir

Khaldieh, S. A. (2000). Learning strategies and writing processes of proficient vs. less-proficient learners of Arabic. Foreign Language Annals, 33(5), 522-533. http://dx.doi.org/10.1111/j.1944-9720.2000.tb01996.x

Khalil, A. (2005). Assessment of language learning strategies used by Palestinian EFL learners. Foreign Language Annals, 38(1), 108-119. http://dx.doi.org/10.1111/j.1944-9720.2005.tb02458.x

Kim, S. (1995). Types and sources of problems in L2 reading: A qualitative analysis of the recall protocols by Korean high school EFL students. Foreign Language Annuals, 28, 49-70. 
Lan, L. R., \& Oxford, R. L. (2003). Language learning strategy profiles of elementary school students in Taiwan. International Review of Applied Linguistics in Language Teaching, 41(4), 339-379.

Lawrence, L. J. (2007). Cognitive and metacognitive reading strategies revisited: Implications for instruction. The Reading Matrix, 7(3), 55-71.

Liu, D. (2004). EFL proficiency, gender, and language learning strategy use among a group of Chinese technological institute English majors. ARECLS-E Journals, 1, 20-28.

Macaro, E. (2001). Learning strategies in foreign and second language classroom. London: Continuum International.

Macintyre, P. D. (2002). Motivation, anxiety, and emotion in second language acquisition. In P. D. Robinson (Ed.), Individual differences in second language acquisition (pp. 45-68). Amsterdam, Netherlands: John Benjamin.

McNamara, T. (1996). Measuring second language performance. London \& New York: Longman.

Mahlobo, E. B. (2003). The relationship between standardised test performance and language learning strategies in English as second language: A case study. Journal for Language Teaching, 37(2), 164-176.

Nisbet, D. L., Tindall, E. R., \& Arroyo, A. A. (2005). Language learning strategies and English proficiency of Chinese university students. Foreign Language Annuals in Proquest Journal, 38(1), 100-108.

O’Malley, J. M., \& Chamot, A. U. (1990). Learning strategies in second language acquisition. New York: Cambridge University Press.

O’Malley, J. M., Chamot, A. U., \& Küpper, L. (1989). Listening comprehension strategies in second language acquisition. Applied Linguistics, 10, 418-437.

Ok, L. K. (2003). The relationship of school year, sex and proficiency on the use of learning strategies in learning English of Korean junior high school students. Asian EFL Journal, 5(3), 1-36.

Oxford, R. L. (1990). Language learning strategies: What every teacher should know. New York: Newbury House Publishers.

Oxford, R. L. (1993). Research on second language learning strategies. Annual Review of Applied Linguistics, 13, 175-187.

Oxford, R. L. (Ed.). (1996). Language learning strategies around the World: Cross-cultural perspectives. Second Language Teaching and Curriculum Center, University of Hawaii: Honolulu.

Oxford, R. (2002). Language learning strategies. In R. Carter, \& D. Nunan (Eds.), The Cambridge guide to teaching English to speakers of otherlanguages (pp. 166-172). Cambridge: Cambridge University Press.

Oxford, R. L., \& Ehrman, M. (1995). Adult's language learning strategies in an intensive foreign language program in the United States. System, 23(3), 359-386.

Pan, L. P. (2006). An experimental study on the teachability of metacognitive strategy in L2 classroom reading. Foreign Language Teaching, 1, 49-54.

Park, Y. (1997). Language learning strategies and English proficiency in Korean University students. Foreign Language Annals, 30(2), 211-221.

Pishghadam, R. (2009). The relationship between the use of learning strategies with gender for learning English and the preferred learning strategies for learning English by Iranian students. Journal of the Literature and Humanities Faculty of Tabriz University, 208, 24-50. Retrieved from www.sid.ir

Pressley, M., \& Gaskins, I. W. (2006). Metacognitively competent reading comprehension is constructively responsive reading: How can such reading be developed in students? Metacognition Learning, 1, 99-113.

Rahimi, M., \& Katal, M. (2010). Iranian university students' metacognitive listening strategies awareness in learning English. Paper presented at the third national conference on education, Tehran, Iran.

Rasekh, Z., \& Ranjbary, R. (2003). Metacognitive strategy training for vocabulary learning. TESL-EJ, 7, 1-18.

Rubin, J. (1975). What the "good language learner" can teach us? TESOL Quarterly, 9, 41-51.

Shokrpour, N., \& Fotovatian, S. (2009). The effects of consciousness raising on metacognitive strategies on EFL students' reading comprehension. ITL International Journal of Applied Linguistics, 3, 221-245.

Snow, C. (2002). Reading for understanding: Toward an $R \& D$ program in reading comprehension. Santa 
Monica, CA: Rand Education.

Stern, H. H. (1975). What can we learn from the good language learner? Canadian Modern Language Review, 31, 304-318.

Sternberg, R. J. (1998). Metacognition, abilities and developing expertise: What makes an expert student? Instructional Science, 26, 127-140. http://dx.doi.org/10.1023/A:1003096215103

$\mathrm{Su}, \mathrm{M}$. (2005). A study of EFL technological and vocational college students' language learning and their self-perceived English proficiency. Electronic Journal of Foreign Language Teaching, 2(1). Retrieved from http://e-flt.nus.edu.sg/Nation

Vandergrift, L. (1996). The listening comprehension strategies of core French high school students. Canadian Modern Language Review, 52, 200-223.

Vandergrift, L. (1997). The Strategies of Second Language (French) listeners: A Descriptive Study. Foreign Language Annals, 30, 387-409. http://dx.doi.org/10.1111/j.1944-9720.1997.tb02362

Vandergrift, L., Goh, C. C. M., Mareschal, C., \& Tafaghodtari, M. H. (2006). The metacognitive awareness listening questionnaire (MALQ): Development and Validation. Language Learning, 56(3), 431-462.

Wen, Q. F. (2003). The successful way of learning English. Shanghai: Shanghai Foreign Language Education Press.

Wenden, A. (1991). Learner strategies for learner autonomy: Planning and implementing learner training for language learners. New York: Prentice Hall.

Wenden, A. (1998). Metacognitive knowledge and language learning. Applied Linguistics, 19(4), 515-537. http://dx.doi.org/10.1093/applin/19.4.515

Wenden, A. L. (2002). Learner development in language learning. Applied Linguistics, 23, 32-55.

Wharton, G. (2000). Language learning strategy use of bilingual foreign language learners in Singapore. Language Learning, 50(2), 203-244. http://dx.doi.org/10.1111/0023-8333.00117

Wharton, G. (2000). Language learning strategy use of bilingual foreign language learners in Singapore. Language Learning, 50(2), 203-243. http://dx.doi.org/10.1111/0023-8333.00117

Young, M. Y. C. (1997). A serial ordering of listening comprehension strategies used by advanced ESL learners in Hong Kong. Asian Journal of English language Teaching, 7, 35-53.

Zhang, D. L., \& Goh, C. (2006). Strategy knowledge and perceived strategy use: Singaporean students' awareness of listening and speaking strategies. Language Awareness, 15(3), 199-219.

\section{Copyrights}

Copyright for this article is retained by the author(s), with first publication rights granted to the journal.

This is an open-access article distributed under the terms and conditions of the Creative Commons Attribution license (http://creativecommons.org/licenses/by/3.0/). 